\title{
PENGARUH KINERJA KEUANGAN TERHADAP NILAI PERUSAHAAN SEBAGAI MANIFESTASI PEMBELAJARAN INVESTASI
}

\author{
Agung Listiadi, Fakultas Ekonomi Unesa \\ agung_296@yahoo.com
}

\begin{abstract}
ABSTRAK
Perusahaan yang menjual sahamnya kepada masyarakat secara go public harus memiliki gambaran yang baik. Gambaran yang baik diperlukan untuk mendapatkan kepercayaan dari investor. Perusahaan dalam upaya mendapatkan kepercayaan dari investor akan memberikan informasi yang sifatnya dapat dipercaya. Informasi ini menggambarkan karakter perusahaan terutama tentang kinerja keuangan. Untuk mengetahui pengaruh nilai perusahaan digunakan teknik analisis regresi. Dari hasil penelitian terdapat pengaruh yang signifikan antara kinerja keuangan terhadap nilai perusahaan, hal ini terjadi disebabkan EMH Semi Strong. Kinerja keuangan yang berpengaruh terhadap nilai perusahaan sebesar 6\%. Hal ini dikarenakan pada tahun 2006 jumlah perusahaan yang nilainya di atas rata-rata kinerja keuangan sebesar 40\%, sedangkan pada tahun 2007 naik menjadi 42\% dan pada tahun 2008 naik lagi menjadi 38\%. Hal ini berarti semua investor masih menggunakan ukuran nilai ROE dalam mengambil keputusan untuk investasi, ketika melakukan investasi di perusahaan yang masuk dalam daftar LQ45 periode 2006 sampai dengan 2008.

Kata kunci : Kinerja keuangan, nilai perusahaan.
\end{abstract}

\begin{abstract}
Companies that sell shares to the public in going public should have a good overview. A good overview is needed to gain the trust of investors. Companies in an effort to gain the confidence of investors will provide information that is credible. It characterizes the character of the company, especially on financial performance. To determine the effect of the financial performance of the company's value are used regression analysis techniques. The survey results a significant influence from the financial performance to the company's value. Effect on the financial performance to the company's value is 6\%. This can be seen in the year 2006 the number of company which had financial performance above the average were $40 \%$, while in 2007 rose to $42 \%$ and in 2008 it was $38 \%$. This illustrates all investors still using ROE value in taking the decision to invest, when to invest in companies included in the list of LQ-45 the period 2006 to 2008. Keywords: financial performance, the company's value.
\end{abstract}

\section{PENDAHULUAN}

Perusahaan merupakan suatu unit kegiatan produksi yang mengelola sumber-sumber ekonomi untuk menyediakan barang dan jasa bagi masyarakat dengan tujuan untuk memperoleh keuntungan dan dapat memuaskan kebutuhan 
masyarakat. Perusahaan bertugas mengolah sumber-sumber ekonomi atau sering disebut faktor-faktor produksi. Pembiayaan merupakan salah satu fungsi perusahaan yang penting bagi keberhasilan usaha suatu perusahaan. Dikatakan penting karena fungsi inilah yang melakukan usaha untuk mendapatkan dana. Baik perusahaan besar maupun kecil membutuhkan dana untuk menjalankan kegiatan usahanya. Dana yang dibutuhkan dapat diperoleh baik melalui pembiayaan dari dalam perusahaan (internal financing) maupun pembiayaan dari luar perusahaan (external financing). Sumber pembiayaan eksternal diperoleh perusahaan dengan melakukan pinjaman kepada pihak lain atau menjual sahamnya kepada masyarakat (go public) di pasar modal. Sedangkan sumber pembiayaan modal internal adalah berupa pemanfaatan laba yang ditahan (retained earnings), yaitu laba yang tidak dibagikan sebagai dividen.

Investor akan menggunakan seluruh informasi relevan yang tersedia ketika berusaha meningkatkan prediksi atas hasil-hasil yang ingin mereka peroleh di masa yang akan datang, sehingga setiap informasi tambahan sangatlah diperlukan. Semakin banyak informasi yang diungkapkan perusahaan mengenainya, semakin besar keyakinan investor karena semakin sedikit pula informasi dari dalam yang perlu dikuatirkan. Perusahaan memberikan informasi berupa kondisi keuangannya yang tercermin dalam kinerja keuangan, prospeknya di masa yang akan datang dan pengungkapan-pengungkapan lainnya. Pengertian kinerja keuangan menurut Copeland dan Weston (1995) adalah pencerminan keputusan-keputusan strategis, operasi dan pembiayaan. Tujuannya adalah untuk membantu investor dalam menginterpretasikan laporan-laporan keuangan perusahaan. Investor berkepentingan mengevaluasi kemampuan perusahaan melalui kinerja keuangannya. Christiawan dan Tarigan (2007) dalam penelitiannya menyatakan Kinerja Keuangan berpengaruh positif terhadap nilai perusahaan. Investor selain menilai perusahaan melalui kinerja keuangan, juga akan berusaha mencari informasiinformasi tambahan untuk menunjang keputusan investasi yang akan diambil. Penelitian ini bertujuan untuk menguji dan menganalisis pengaruh dari Kinerja Keuangan terhadap nilai perusahaan dalam laporan tahunan perusahaan atas respon pasar. Selain itu penelitian ini juga bertujuan sebagai manifestasi pembelajaran pola-pola berinvestasi.

Informasi akuntansi merupakan dasar yang objektif dan bukan subjektif sebagai penilaian kinerja manajer. Agar informasi akuntansi berguna bagi pihakpihak yang membutuhkannya, maka laporan keuangan harus disusun secara objektif. Informasi akuntansi sangat bermanfaat untuk menilai pertanggungjawaban kinerja manajer. Dari informasi akuntansi berupa laporan keuangan dapat dibuat suatu analisis rasio keuangan. Analisis rasio keuangan merupakan instrumen analisis prestasi perusahaan yang menjelaskan berbagai hubungan dan indikator kinerja keuangan yang ditujukan untuk menunjukkan perubahan dalam kondisi keuangan atau prestasi operasi di masa lalu dan dipergunakan untuk melakukan prediksi dimasa yang akan datang. Makna dan kegunaan rasio keuangan dalam praktik bisnis pada kenyataannya bersifat subyektif, bergantung pada untuk apa suatu analisis dilakukan dalam konteks apa analisis tersebut diaplikasikan.

Salah satu tahapan dalam proses akuntansi yang penting untuk keperluan pengambilan keputusan manajemen adalah tahap interprestasi laporan akuntansi, yang didalamnya mencakup rasio keuangan. Rasio keuangan yang merupakan 
bentuk informasi akuntansi yang penting bagi perusahaan selama suatu periode tertentu. Berdasarkan rasio tersebut, dapat dilihat kinerja keuangan, maupun kinerja ekonomis di masa depan. Karena penilaian kinerja pada dasarnya merupakan penilaian perilaku manusia dalam melaksanakan peran yang dimainkannya dalam mencapai tujuan organisasi atau perusahaan. Berdasar laporan keuangan diketahui kinerja keuangan perusahaan dengan cara melakukan analisis laporan keuangan melalui perhitungan rasio-rasio keuangan. Analisis rasio merupakan bentuk atau cara yang umum digunakan dalam analisis laporan finansial. Dengan kata lain, diantara alat-alat analisis yang selalu digunakan untuk mengukur kekuatan atau kelemahan yang dihadapi perusahaan di dibidang keuangan atau kinerja keuangan, adalah analisis rasio (financial ratio analysis).

Pemegang saham memiliki kepentingan pada laporan keuangan untuk mendapatkan informasi tentang posisi keuangan, kinerja dan perubahan pada posisi keuangan menurut Belkaoui (2000). Tentunya pemegang saham memiliki harapan bahwa kinerja keuangan perusahaan dalam kondisi optimal. Dengan demikian salah satu gambaran yang menunjukkan prospek bagus suatu perusahaan adalah kinerja keuangan yang bagus pula. Sedangkan pengertian kinerja keuangan menurut Copeland dan Weston (1995) adalah pencerminan keputusan-keputusan strategis, operasi dan pembiayaan. Sedangkan Jumingan (2006) menyatakan bahwa kinerja keuangan adalah gambaran prestasi yang dicapai perusahaan dalam kegiatan operasionalnya. Pengertian kinerja keuangan menurut Christiawan dan Tarigan (2007) adalah penentuan ukuran-ukuran tertentu yang dapat mengukur keberhasilan suatu perusahaan dalam menghasilkan laba. Dengan demikian kinerja keuangan terkait dengan penentuan ukuran-ukuran tertentu yang dapat mengukur keberhasilan suatu perusahaan dalam kegiatan operasionalnya. Perusahaan banyak memerlukan biaya dalam menjalankan kegiatan operasionalnya, oleh karena itu hanya perusahaan yang mempunyai prospek bagus saja yang mampu memenuhi biaya melalui berbagai sumber pendanaan.

Peranan manajer adalah sangat luas, keterlibatannya meliputi keseluruhan dari kegiatan perusahaan. Dengan adanya pergeseran persaingan yang semakin kuat, pengaruh inflasi, perubahan teknologi, kepedulian terhadap lingkungan hidup, energi, masalah social, peraturan-peraturan pemerintah serta adanya tuntutan sistem perdagangan bebas, manajer keputusannya harus tetap akurat sesuai dengan tujuan atau sasaran perusahaan. Dalam mengambil keputusan manajemen maka diperlukan informasi-informasi tentang keadaan perusahaan. Informasi yang dimaksud adalah kinerja keuangan perusahaan. Sedangkan kinerja keuangan perusahaan mencerminkan kemampuan perusahaan dalam mengelolah operasional perusahaan. Kinerja keuangan suatu perusahaan sangat bermanfaat bagi berbagai pihak seperti investor, kreditur, analis, konsultan keuangan, pialang pemerintah dan pihak manajemen sendiri. Kinerja keuangan mengukur kinerja perusahaan dalam memperoleh laba dan nilai pasar. Kinerja keuangan perusahaan merupakan hasil dari banyak keputusan individual yang dibuat secara terus menerus oleh manajemen. Oleh karena itu untuk menilai kinerja keuangan suatu perusahaan, perlu dilibatkan analisa dampak keuangan kumulatif dan ekonomi dari keputusan dan mempertimbangkannya dengan menggunakan ukuran komparatif.

Kinerja yang baik akan memberikan pengharapan yang baik pula bagi para pengambil keputusan investasi. Untuk mengukur kinerja keuangan menurut 
Miller (2008) adalah sebagai berikut : "So what are these key performance measures? We believe the key measures are driven by three critical issues facing every general manager. These three issues are profitability, size of the business, and growth of the business over time. Consequently, financial performance measures that assess profitability, size, and growth rates are essential to monitor overall financial performance and progress.

Kunci ukuran kinerja berpedoman pada tiga isu kritis yang dihadapi oleh tiap-tiap General manajer. Tiga isu ini adalah profitabilitas, ukuran bisnis, dan pertumbuhan bisnis dari waktu ke waktu. Sebagai konsekwensi, ukuran kinerja keuangan yang tercermin dari profitabilitas, ukuran, dan laju pertumbuhan adalah penting untuk dimonitor secara keseluruhan kinerja keuangan dan kemajuannya. Setiap sistem pengukuran dan penilaian terhadap kinerja bagian-bagian di dalam perusahaan harus dimulai dengan suatu pemyataan yang jelas mengenai tujuan yang hendak dicapai. Jika hal ini tidak dilakukan, sistem tersebut mungkin akan mengukur hal yang salah, manajemen akan menarik kesimpulan yang salah dari hasil pengukuran yang dilakukan tersebut, dan akibatnya adalah manajemen melakukan tindakan yang salah. Secara umum tujuan pengukuran dan penilaian kinerja menurut Mulyadi (1986) adalah : 1.) Untuk menentukan kontribusi suatu bagian dalam perusahaan terhadap organisasi perusahaan secara keseluruhan; 2.) Untuk memberikan dasar bagi penilaian mutu kinerja manajer dalam menjalankan perusahaan; 3.) Untuk memberikan motivasi bagi manajer di dalam menjalankan tugasnya seirama dengan tujuan pokok organisasi perusahaan secara keseluruhan.

Dalam situasi tertentu, tujuan pengukuran dan penilaian kinerja tersebut harus dinyatakan secara khusus dan eksplisit. Jika menejemen ingin menilai kontribusi suatu bagian sebagai kesatuan usaha yang terpisah, ukuran yang digunakannya harus meliputi semua faktor yang secara langsung dapat diusut hubungannya dengan bagian yang bersangkutan dan mengabaikan faktor-faktor lainnya. Jika manajemen ingin menilai kinerja manajer bagian tersebut, harus dipilih ukuran yang berhubungan dengan faktor-faktor yang dapat dikendalikan oleh manajer tersebut. Jadi data yang relevan di dalam pengukuran ini harus berada di dalam bidang pertanggungjawaban manajer tersebut.

Dalam membahas metode pengukuran kinerja keuangan, perusahaan harus didasarkan pada data keuangan yang dipublikasikan yang dibuat sesuai dengan prinsip akuntansi keuangan yang berlaku umum. Laporan ini merupakan data yang paling umum yang tersedia untuk tujuan tersebut, walaupun seringkali tidak mewakili hasil dan kondisi ekonomi. Laporan keuangan memuat hasil investasi operasi dan pembiayaan perusahaan, maka fokus akan diarahkan pada hubungan dan indikator keuangan yang memungkinkan analisa penilaian kinerja masa lalu dan juga proyeksi hasil masa depan dimana akan menekankan pada manfaat serta keterbatasan yang terkandung didalamnya. Perusahaan kemungkinan akan menggunakan informasi akuntansi untuk menilai kinerja manajer. Kemungkinan lain adalah informasi akuntansi digunakan bersamaan dengan informasi non akuntansi untuk menilai kerja manajernya. Kinerja manajer diwujudkan dalam berbagai kegiatan mencapai tujuan perusahaan. Dan karena setiap kegiatan itu memerlukan sumber daya maka kinerja manajemen akan tercermin dari penggunaan sumber daya untuk mencapai tujuan perusahaan. 
Rasio merupakan alat yang dinyatakan dalam artian relatif maupun absolut untuk menjelaskan hubungan tertentu antara faktor yang satu dengan faktor yang lain dari suatu laporan finansial. Rasio dapat dihitung berdasarkan financial statement yang telah tersedia yang terdiri dari neraca (balance sheet) dan rugi-laba (income statement). Informasi yang diperoleh dari kondisi intern perusahaan yang lazim digunakan adalah informasi laporan keuangan. Informasi fundamental dan teknikal tersebut dapat digunakan sebagai dasar bagi investor untuk memprediksi return, risiko atau ketidak pastian, jumlah, waktu, dan faktor lain yang berhubungan dengan aktivitas investasi di pasar modal. Dari berbagai rasio keuangan terdapat beberapa rasio dan informasi keuangan perusahaan yang dapat digunakan untuk membantu memprediksi oleh investor. Rasio keuangan menurut Prastowo dan Rifka (2005) dikelompokkan dalam lima jenis yaitu: 1.) Rasio likuiditas, yaitu Rasio yang mengukur kemampuan suatu perusahaan dalam memenuhi kewajiban jangka pendeknya. Rasio ini meliputi pula rasio-rasio yang mengukur efisiensi penggunaan aktiva lancar; 2.) Rasio profitabilitas, yaitu Rasio yang mengukur kemampuan perusahaan dalam menghasilkan laba, relatif dibandingkan dengan aktiva(investasi) yang digunakan; 3.) Rasio kinerja operasi, yaitu Rasio yang mengukur efisiensi operasi perusahaan; 4.) rasio solvabilitas (leverage) yaitu Rasio yang mengukur tingkat perlindungan para kreditor jangka panjang; 5.) Rasio pemanfaatan aktiva yaitu Rasio yang mengukur efisiensi dan efektivitas penggunaan aktiva dalam mendukung penjualan perusahaan.

Para investor harus diperhatikan oleh perusahaan dengan cara memaksimalkan nilai perusahaan tersebut, nilai perusahaan merupakan ukuran keberhasilan atas pelaksanaan fungsi-fungsi keuangan. Penilaian prestasi suatu perusahaan dapat dilihat dari kemampuan perusahaan itu untuk menghasilkan laba. Laba perusahaan selain merupakan indikator kemampuan perusahaan memenuhi kewajiban bagi para penyandang dananya juga merupakan elemen dalam penciptaan nilai perusahaan yang menunjukkan prospek perusahaan di masa yang akan datang. Tingkat profitabilitas perusahaan dapat diukur dari beberapa aspek, yaitu berdasarkan pada rasio profitabilitas. Rasio profitabilitas menurut Brigham dan Houston (2006) terdiri dari rasio yaitu: gross profit margin (GPM), basic earning power (BEP), return on asset (ROA) atau sering disebut return on investment $(\mathrm{ROI})$, dan return on equity (ROE).

Untuk mengukur kinerja perusahaan dari sisi pandang investor menurut Brigham dan Houston (2006) adalah dengan menggunakan pendekatan return on equity (ROE). Alasan penggunaan rasio tersebut menurut Brigham dan Houston (2006) adalah para pemegang saham melakukan investasi untuk mendapatkan pengembalian atas uang mereka dan rasio ini menunjukkan seberapa baik mereka telah melakukan hal tersebut dilihat dari kacamata akuntansi. Hal ini diperkuat dengan pernyataan Halsey, dkk (2005) yang menyatakan pengembalian atas investasi merupakan ukuran kinerja yang diakui secara luas. Ukuran ini memungkinkan untuk menilai pengembalian perusahaan terhadap resiko investasi modal. Bodie, dkk (2006) juga menguatkan alasan penggunaan rasio return on equity dengan menyatakan imbal hasil atas investasi adalah ukuran yang paling populer, perusahaan dengan tingkat imbal hasil yang tinggi seharusnya lebih mampu menghasilkan uang dipasar modal karena mereka menawarkan imbal hasil yang lebih baik kepada calon investornya. Untuk mendapatkan nilai return on equity menurut Bodie, dkk (2006) adalah : 


$$
\mathrm{ROE}=\frac{\text { Laba Bersih }}{\text { Ekuitas }}
$$

Return on equity adalah rasio yang mengukur imbal hasil rata-rata dari total kepemilikan pemegang saham menurut Jumingan (2006). Rasio ini merupakan cara untuk mengukur tingkat profitabilitas dari perusahaan. Net income merupakan tujuan dari perusahaan dan rasio ini menunjukkan bagaimana tujuan utama itu telah dicapai. Rasio return on equity yang rendah menunjukkan perusahaan tidak begitu berhasil karena tidak efisien dan tidak efektifnya produksi, distribusi, keuangan serta kondisi umum perusahaan yang tidak menguntungkan.

Kemampuan perusahaan bersumber dari produktivitas ekonomis dari dana pinjaman dan modal sendiri yang ditanamkan dalam bentuk aktiva dan keseluruhan efisiensi operasi perusahaan yang bersangkutan. Rasio yang rendah mencerminkan adanya kelebihan investasi dalam aktiva terkait dengan volume penjualan, rendahnya volume penjualan dibandingkan dengan biaya-biaya yang telah dikeluarkan untuk mencapai penjualan itu. Rendahnya rasio juga menggambarkan ketidakefisienan manajemen dalam produksi, pembelian, strategi pemasaran dan operasi pada umumnya. Pada akhirnya rasio akuntansi yang paling penting atau jumlah akhir (bottom line) adalah rasio laba bersih terhadap ekuitas saham (ROE) yang diukur sebagai tingkat pengembalian ekuitas saham biasa dan pengembalian investasi dari assets menurut Brigham dan Houston (2006). Semakin tinggi nilai return on equity maka semakin baik tingkat imbal hasil investasi.

Banyak ekonom melihat keterkaitan antara fluktuasi dalam investasi dan fluktuasi dalam pasar saham. Istilah saham mengacu pada bagian dalam kepemilikan perusahaan, dan pasar saham adalah pusat dimana saham-saham ini diperdagangkan. Harga saham cenderung menjadi tinggi ketika perusahaan mempunyai banyak peluang bagi investasi yang menguntungkan, karena peluang laba ini berarti pendapatan masa depan yang lebih tinggi untuk pemegang saham. Jadi harga saham mencerminkan insentif untuk investasi. Sebuah perusahaan memiliki nilai bagi pemiliknya karena aset bersih perusahaan merupakan akumulasi kesejahteraan (wealth) yang dapat digunakan untuk memenuhi kebutuhan. Jadi, kepemilikan perusahaan adalah klaim atas kesejahteraan. Teori surplus bersih memandang akuntansi sebagai sistem pencatatan penciptaan dan distribusi kesejahteraan. Oleh karena itu terdapat hubungan antara nilai perusahaan dan informasi akuntansi. Penyusunan earnings dilakukan oleh manajemen yang lebih mengetahui kondisi di dalam perusahaan, kondisi tersebut dapat menimbulkan masalah karena manajemen sebagai pihak yang memberikan informasi tentang kinerja perusahaan dievaluasi dan dihargai berdasarkan laporan yang dibuatnya sendiri.

Pada beberapa perusahaan besar yang sahamnya dijual ke masyarakat, pasar saham juga merupakan tolak ukur prestasi perusahaan, hal ini diungkapkan oleh Copeland dan Weston (1995). Beberapa konsep nilai yang menjelaskan nilai suatu perusahaan menurut Brigham dan Houston (2006) adalah: nilai nominal, nilai pasar, nilai intrinsik, nilai buku dan nilai likuidasi. Pernyataan Brigham diperkuat oleh Christiawan dan Tarigan (2007) yang menyatakan beberapa konsep nilai 
yang menjelaskan nilai suatu perusahaan adalah: nilai nominal, nilai pasar, nilai intrinsik, nilai buku dan nilai likuidasi.

Nilai nominal adalah nilai yang tercantum secara formal dalam anggaran dasar perseroan, disebutkan secara eksplisit dalam neraca perusahaan, dan juga ditulis jelas dalam surat saham kolektif. Nilai pasar, sering disebut kurs adalah harga yang terjadi dari proses tawar-menawar di pasar saham. Nilai ini hanya dapat ditentukan jika saham perusahaan dijual di pasar saham, nilai pasar menurut Halsey, dkk (2005) dianggap lebih relevan. Nilai pasar saham menurut Bodie, dkk (2006) memperhitungkan nilai perusahaan sebagai entitasyang terus beroperasi. Dengan kata lain, harga pasar mencerminkan nilai Sekarang dari arus kas yang diharapkan di masa depan. Nilai intrinsik merupakan konsep yang paling abstrak, karena mengacu pada perkiraan nilai riil suatu perusahaan. Nilai perusahaan dalam konsep nilai intrinsik ini bukan sekadar harga dari sekumpulan aset, melainkan nilai perusahaan sebagai entitas bisnis yang memiliki kemampuan menghasilkan keuntungan di kemudian hari.

Sedangkan nilai buku adalah nilai perusahaan yang dihitung dengan dasar konsep akuntansi. Secara sederhana dihitung dengan membagi selisih antara total aktiva dan total utang dengan jumlah saham yang beredar. Nilai likuidasi itu adalah nilai jual seluruh aset perusahaan setelah dikurangi semua kewajiban yang harus dipenuhi. Nilai sisa itu merupakan bagian para pemegang saham. Nilai likuidasi dapat dihitung dengan cara yang sama dengan menghitung nilai buku, yaitu berdasarkan neraca performa yang disiapkan ketika suatu perusahaan akan dilikuidasi. Menurut Bodie, dkk (2006) ukuran yang lebih baik untuk harga terendah saham adalah nilai likuidasi. Ukuran ini menunjukkan jumlah uang yang dapat direalisasi dengan melikuidasi perusahaan. Jika mekanisme pasar berfungsi dengan baik, maka harga saham tidak mungkin berada di bawah nilai likuidasi. Karena nilai likuidasi ini hanya dihitung bila perusahaan akan dilikuidasi maka investor dapat menggunakan nilai buku sebagai pengganti untuk tujuan yang sama yaitu memperkirakan batas bawah harga saham. Nilai buku menurut Bodie, dkk (2006) adalah kekayaan bersih perusahaan yang dilaporkan di neraca. Nilai buku perusahaan merupakan hasil dari penerapan serangkaian aturan akrual untuk menyebarkan harga perolehan aset selama jangka waktu tertentu.

Menurut Bodie, dkk (2006) selalu ada kemungkinan perusahaan yang sahamnya terjual pada harga dibawah nilai bukunya. Sehingga nilai buku dapat digunakan sebagai batas aman mengukur nilai perusahaan untuk keperluan investasi. Namun demikian ada beberapa catatan yang harus diperhatikan dalam memahami konsep nilai buku ini. Pertama, sebagian besar aset dinilai dalam nilai historis. Karena itu pada beberapa aset nilai jualnya dapat jadi jauh lebih tinggi dari nilai bukunya. Kedua, didalam aset kadang terdapat aktiva tak berwujud, yang dalam likuidasi sering tidak memiliki nilai jual. Ketiga, nilai buku sangat dipengaruhi oleh metode dan estimasi akuntansi seperti metode penyusutan aktiva tetap, metode penilaian persediaan, dan lain-lain. Keempat, ada kemungkinan timbul kewajiban-kewajiban yang tidak tercatat dalam laporan keuangan karena belum diatur pelaporannya oleh standar akuntansi keuangan. Berdasarkan penjelasan di atas dapat disimpulkan bahwa konsep yang paling representatif untuk menentukan nilai perusahaan adalah pendekatan konsep nilai intrinsik. Tetapi memperkirakan nilai intrinsik sangat sulit, sebab untuk menentukannya orang membutuhkan kemampuan mengidentifikasi variabel-variabel signifikan 
yang menentukan keuntungan suatu perusahaan.Variabel itu berbeda dari satu perusahaan ke perusahaan yang lain. Selain itu, penentuan nilai intrinsik juga memerlukan kemampuan memprediksi arah kecenderungan yang akan terjadi di kemudian hari. Karena itulah, maka nilai pasar digunakan dengan alasan kemudahan data juga didasarkan pada penilaian yang moderat. Manajer yang sekaligus pemegang saham akan meningkatkan nilai perusahaan, karena dengan meningkatnya nilai perusahaan maka nilai kekayaannya sebagai individu pemegang saham akan ikut meningkat pula.

Laba yang kurang berkualitas dapat terjadi karena dalam menjalankan bisnis perusahaan, manajemen bukan merupakan pemilik perusahaan. Pemisahan kepemilikan ini akan dapat menimbulkan konflik dalam pengendalian dan pelaksanaan pengelolaan perusahaan yang menyebabkan para manajer bertindak tidak sesuai dengan keinginan para pemilik.

Konflik yang terjadi akibat pemisahan kepemilikan ini disebut dengan konflik keagenan. Beberapa mekanisme yang dapat digunakan untuk mengatasi masalah keagenan tersebut adalah dengan meningkatkan kepemilikan manajerial. Beberapa mekanisme (mekanisme corporate governance) seperti mekanisme internal, struktur dan dewan komisaris, serta mekanisme eksternal seperti pasar untuk kontrol perusahaan diharapkan dapat mengatasai masalah keagenan tersebut. Dengan meningkatkan kepemilikan saham oleh manajer, diharapkan manajer akan bertindak sesuai dengan keinginan para principal karena manajer akan termotivasi untuk meningkatkan kinerja. Kemampuan dewan komisaris untuk mengawasi merupakan fungsi yang positif dari porsi dan independensi dari dewan komisaris eksternal.

Dewan komisaris juga bertanggung jawab atas kualitas laporan yang disajikan. Komite audit yang bertanggung jawab untuk mengawasi laporan keuangan, mengawasi audit eksternal, dan mengamati sistem pengendalian internal juga konflik keagenan yang mengakibatkan adanya sifat opportunistic manajemen akan mengakibatkan rendahnya kualitas laba. Rendahnya kualitas laba akan dapat membuat kesalahan pembuatan keputusan kepada para pemakainya seperti para investor dan kreditor, sehingga nilai perusahaan akan berkurang. Menurut Tobin dalam Mankiw (2003) nilai perusahaan didasarkan pada suatu rasio yang dinyatakan dengan rasio Tobin's Q, dimana numerator Tobin's Q adalah nilai modal perekonomian yang ditentukan oleh pasar saham. Keunggulan Tobin's Q sebagai ukuran dari insentif untuk investasi adalah bahwa hal ini mencerminkan profitabilitas modal masa depan yang diharapkan serta profitabilitas sekarang. Teori investasi Tobin's Q menekankan bahwa keputusan investasi bergantung tidak hanya pada kebijakan ekonomi saat ini tetapi juga pada kebijakan yang diharapkan berlaku dimasa depan. Namun demikian tujuan akuntansi adalah menyajikan informasi, terutama bagi investor, yang diharapkan dapat digunakan sebagai dasar mengambil keputusan. Agar bermanfaat dalam proses pengambilan keputusan maka informasi tersebut harus relevan dan reliabel.

Informasi yang relevan adalah informasi yang memiliki potensi untuk mempengaruhi keputusan yang diambil, sedangkan informasi yang reliabel adalah informasi yang tidak menyesatkan (dapat diandalkan). Sayangnya, informasi yang relevan sering kali tidak reliabel, dan sebaliknya informasi yang reliabel sering kali tidak relevan. Sampai saat ini akuntansi lebih mementingkan reliabilitas dari relevansi, sehingga informasi yang akhirnya tersaji sering kali kurang relevan. 
Teori surplus bersih menunjukkan masih tingginya relevansi informasi akuntansi karena tetap dapat digunakan dalam perhitungan nilai perusahaan. Untuk mengukur nilai perusahaan menurut Goukasian dan Whitney (2008) dapat dipergunakan rumus Tobin's Q sebagai berikut : To capture the future performance, we use the book-to-market ratio, which is a proxy for future investment opportunities (Tobin's Q). We believe our results capture some market/industry trends, and to avoid the impact of those trends on our analysis, we conduct our analysis using industry-adjusted value of the firms as well Tobin' $\mathrm{s} \mathrm{Q}$ is the combined market value of all the companies on the stock market should be about equal to their replacement costs. The $Q$ ratio is calculated as the market value of a company divided by the replacement value of the firm's assets:

\section{$Q$ Ratio $=$ Total Market Value of The Firm \\ Total Asset Value}

Untuk menggambarkan capaian masa depan dipergunakan perbandingan book-to-market, yang mampu mewakili peluang investasi dimasa depan ( Tobin'S Q). Untuk menggambarkan beberapa kecenderungan market/industry, dan untuk menghindari dampak kecenderungan itu semua atas analisa tersebut, dengan melakukan analisa menggunakan nilai industry-adjusted perusahaan sebagaimana Tobin' s Q adalah kombinasi nilai/harga pasar dari semua nilai perusahaan pada bursa saham yang seharusnya sepadan dengan nilai replacement atau penggantian. Rasio Q dihitung berdasarkan nilai/harga pasar suatu perusahaan yang dibagi oleh nilai asset perusahaan. Istilah saham (stock) mengacu pada bagian dalam kepemilikan perusahaan, dan pasar saham (stock market) adalah pasar di mana saham-saham ini diperdagangkan. Harga saham cenderung menjadi tinggi ketika perusahaan mempunyai banyak peluang bagi investasi yang menguntungkan, karena peluang laba ini berarti pendapatan masa depan yang lebih tinggi untuk pemegang saham. Harga saham mencerminkan insentif untuk investasi. Berdasarkan pendapat diatas James Tobin menyatakan bahwa perusahaan mendasarkan keputusan investasinya pada rasio yang disebut Tobin's Q.

Seperti dijelaskan sebelumnya, investor yang rasional dan memiliki informasi akan mencari informasi mengenai sekuritas. Meskipun demikian, tidak ada jaminan bahwa seluruh individu akan bertindak dengan cara yang sama terhadap informasi yang sama. Sebagai contoh, mereka mungkin memiliki keyakinan awal yang berbeda-beda. Beberapa di antara mereka mungkin memiliki keahlian lebih untuk menganalisis informasi laporan keuangan. Dalam satu hal, model teori keputusan dapat dianggap seperti mobil. Teori ini memberi kendaraan untuk memproses informasi, namun tidak ada yang menjamin bahwa perilaku mengemudi adalah identik, atau bahwa mereka semua mengambil rute yang sama untuk mencapai tujuan. Akibatnya, ada kemungkinan bahwa investor yang berbeda-beda menunjukkan reaksi berbeda-beda pula terhadap informasi yang sama, meskipun mereka semuanya terus bertindak rasional. Namun, investor berinteraksi dalam suatu pasar, dan masing-masing mengambil keputusankeputusan beli/jual mengenai beragam sekuritas. Mengingat harga saham suatu sekuritas merupakan hasil permintaan dan penawaran sekuritas oleh investor, lalu bagaimana harga pasar dapat sepenuhnya mencerminkan seluruh informasi yang 
tersedia ketika individu-individu yang mengajukan penawaran dan permintaan itu berbeda-beda. Harus ditekankan bahwa argumen ini berasumsi bahwa keputusankeputusan individu sifatnya independen, sehingga adanya perbedaan antar individu akan menghapuskan dampak atas harga. Dalam suatu pasar sekuritas yang efisien, harga-harga sepenuhnya mencerminkan informasi yang tersedia, dan perubahan-perubahan harga dalam pasar seperti ini akan berperilaku acak dari waktu ke waktu. Efisiensi didefinisikan secara relatif terhadap informasi atas saham. Jika setumpuk informasi ini tidak lengkap, katakanlah karena adanya informasi dari orang dalam, atau karena informasinya keliru, maka harga-harga sekuritasnya pun akan salah. Meskipun demikian, secara garis besar dapat dikatakan bahwa perbedaan-perbedaan ini dapat diambil rata-ratanya, sehingga harga pasar memiliki kualitas yang lebih unggul dibandingkan dengan kualitas pemrosesan informasi dari perdagangan individu di pasar. Meskipun demikian, argumen ini berasumsi bahwa investor mengevaluasi informasi-informasi baru secara independen. Teori pasar sekuritas yang efisien membahas mengenai interaksi antar investor dalam suatu pasar sekuritas. Teori pasar sekuritas yang efisien memprediksi bahwa harga-harga sekuritas yang dihasilkan dari interaksi ini memiliki beberapa ciri yang menarik. Pada intinya, harga-harga ini sepenuhnya mencerminkan keahlian investor memproses informasi dan pengetahuan secara kolektif dan rasional.

Konsep mengenai seorang individu yang rasional bermakna bahwa dalam membuat keputusan-keputusan, tindakan yang dipilih adalah berdasarkan pada informasi-informasi yang menghasilkan utilitas tertinggi yang diharapkan. Hal ini menyiratkan bahwa individu tersebut dalam rangka menghasilkan utilitas tertinggi yang diharapkan akan mencari informasi tambahan yang berkaitan dengan keputusan tersebut. Efisiensi pasar sekuritas memiliki implikasi-implikasi penting bagi akuntansi keuangan. Salah satu implikasinya adalah bahwa hal ini langsung mengarah pada konsep pengungkapan sepenuhnya, Scott (2003). Dalam konsep pengungkapan sepenuhnya ini, dengan meningkatkan muatan informasi laporan keuangan, termasuk informasi tambahan dalam bentuk catatan-catatan maupun laporan tambahan lainnya, maka tidak saja membantu mempertahankan keunggulan kompetitif perusahaan, namun juga meningkatkan nilai perusahaan dengan mengurangi dampak informasi dari dalam yang merugikan. Jika investor memang menganggap bahwa informasi-informasi yang diungkapkan tersebut berguna, hal ini akan tampak sebagai respon harga-harga sekuritas terhadap informasi tersebut. Sehingga dengan melihat pola-pola keputusan yang diambil investor inilah, maka hal tersebut merupakan manifestasi pembelajaran berinvestasi. Informasi yang dikandung dalam sebuah laporan tahunan akan digunakan oleh para investor untuk membantunya membuat ekspektasi tentang laba dan deviden dimasa mendatang, Brigham dan Houston (2006). Oleh karena itu laporan tahunan sudah jelas akan mendapat perhatian besar dari para investor. Laporan keuangan merupakan laporan tahunan yang dibuat untuk memenuhi ekspektasi investor. Didalam laporan keuangan tersebut akan tergambarkan kinerja keuangan perusahaan. Bila kinerja keuangan yang tercermin dalam return on equity dan return on assets tinggi, maka akan mendorong pertumbuhan nilai perusahaan menurut Bodie, dkk (2006).

Christiawan dan Tarigan (2007) dalam penelitiannya menyatakan Kinerja Keuangan berpengaruh positif terhadap nilai perusahaan. Penelitian ini 
mengambil sample sebesar 137 perusahaan yang terdapat di Bursa Efek Jakarta selama tiga periode yaitu dari tahun 2003 sampai dengan 2005. Kinerja keuangan diukur dengan menggunakan ROA. Nilai perusahaan dihitung dari nilai pasar perusahaan dibagi dengan total assets. Dalam penelitiannya Christiawan dan Tarigan (2007) menyarankan agar pengukuran kinerja keuangan dapat menggunakan ROE dan nilai perusahaan dapat menggunakan Tobin's Q. Berdasarkan saran tersebut maka perbedaan penelitian Christiawan dan Tarigan (2007) dengan penelitian ini adalah Christiawan dan Tarigan (2007) menggunakan dua variabel bebas. Pengukuran kinerja keuangan menggunakan ROE dan pengukuran nilai perusahaan menggunakan Tobin's Q.

Pihak manajemen selalu berusaha keras untuk dapat meningkatkan nilai perusahaan yang dikelolanya. Kinerja keuangan dapat dipergunakan oleh investor sebagai bahan pertimbangan dalam mengambil keputusan untuk berinvestasi. Investor memiliki harapan bahwa pengungkapan informasi yang dilakukan oleh pihak manajemen perusahaan tidak bersifat assymetri information. Pihak manajemen perusahaanpun sebaliknya berusaha memberikan pengungkapan informasi kepada investor dengan sebanyak-banyaknya, dengan harapan bahwa investor memiliki keyakinan atas pengungkapan oleh pihak manajemen.

Untuk memberikan keyakinan kepada para investor, maka pihak manajemen berusaha dengan memberikan pengungkapan sebanyak-banyaknya pada investor. Pengungkapan akan Kinerja keuangan, diharapkan mampu untuk memberikan dampak terhadap nilai perusahaan. Pemegang saham dan manajer masing-masing berkepentingan memaksimalkan tujuannya. Konflik kepentingan terjadi jika keputusan manajer hanya akan memaksimalkan kepentingannya dan tidak sejalan dengan kepentingan pemegang saham. Perilaku manajer dalam situasi konflik kepentingan dan perilaku investor inilah yang menarik untuk diteliti. Berdasarkan pada hal ini, maka kerangka konseptual penelitian dapat digambarkan sebagai berikut

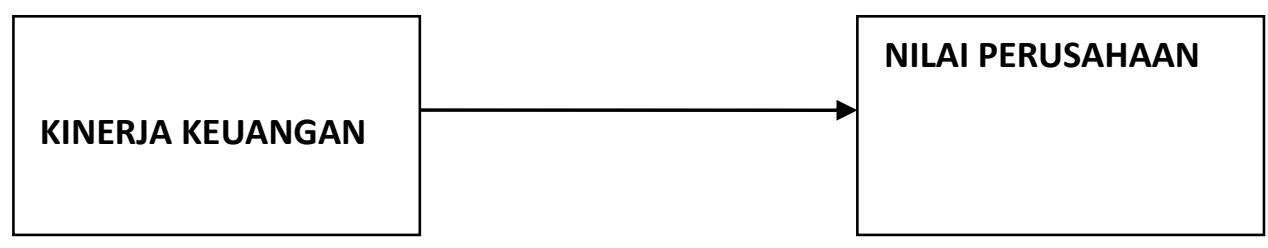

\section{Gambar 1. Kerangka Konseptual Penelitian}

Berdasarkan pada gambar diatas, Efisiensi pasar sekuritas memiliki implikasi-implikasi penting bagi akuntansi keuangan. Salah satu implikasinya adalah bahwa hal ini langsung mengarah pada konsep pengungkapan sepenuhnya. Efisiensi ini menyiratkan bahwa bukan bentuk dari pengungkapan, namun muatan informasi Dalam teori pasar yang efisien, akuntansi dianggap bersaing dengan sumber-sumber informasi lainnya seperti media berita, analis keuangan, dan bahkan harga pasar itu sendiri. Namun harus disadari bahwa investor dalam mengambil keputusan didasarkan pada rasionalitas untuk memenuhi ekspektasinya. Untuk dapat mengambil keputusan yang rasional dibutuhkan informasi yang secara rasional dapat menunjang dan dapat dipergunakan dalam memperhitungkan ekspektasi investor. Kinerja keuangan yang tercermin dalam 
laporan keuangan adalah informasi formal yang dipergunakan oleh investor dalam memperhitungkan ekspektasinya. Sebagai sarana untuk memberi informasi kepada investor, akuntansi hanya dapat bertahan jika sifatnya relevan, andal, tepat waktu dan hemat biaya dibandingkan dengan sumber-sumber lainnya. Kinerja keuangan dalam return on equity yang tinggi mampu meningkatkan citra perusahaan dimata investor sehingga terjadi peningkatan nilai perusahaan. Kinerja keuangan adalah salah satu sumber informasi bagi investor dan akan memiliki dampak yang semakin baik terhadap nilai perusahaan.

Pasar yang efisien tergantung pada asumsi bahwa semua pelaku pasar mengolah informasi secara rasional dan secara rata-rata informasi yang dimiliki semua pelaku pasar adalah benar. Ada kemungkinan bahwa investor yang berbeda-beda menunjukkan reaksi berbeda-beda pula terhadap informasi yang sama, meskipun mereka semuanya terus bertindak rasional.

Kinerja keuangan suatu perusahaan sangat bermanfaat bagi berbagai pihak seperti investor, kreditur, analis, konsultan keuangan, pialang pemerintah dan pihak manajemen sendiri. Kinerja keuangan mengukur kinerja perusahaan dalam memperoleh laba dan nilai pasar. Kinerja keuangan perusahaan merupakan hasil dari banyak keputusan individual yang dibuat secara terus menerus oleh manajemen. Pengertian kinerja keuangan menurut Copeland dan Weston (1995) adalah pencerminan keputusan-keputusan strategis, operasi dan pembiayaan. Dari penelitian yang dilakukan oleh Christiawan dan Tarigan (2007) dalam penelitiannya menyatakan kinerja keuangan berpengaruh secara positif terhadap nilai perusahaan. Informasi yang dikandung dalam sebuah laporan tahunan akan digunakan oleh para investor untuk membantunya membuat ekspektasi tentang laba dan deviden dimasa mendatang Brigham dan Houston (2006). Oleh karena itu laporan tahunan sudah jelas akan mendapat perhatian besar dari para investor. Laporan keuangan merupakan laporan tahunan yang dibuat untuk memenuhi ekspektasi investor. Didalam laporan keuangan tersebut akan tergambarkan kinerja keuangan perusahaan. Bila kinerja keuangan yang tercermin dalam return on equity lebih tinggi dari imbal hasil yang disyaratkan, maka akan mendorong pertumbuhan nilai perusahaan menurut Bodie, dkk (2006). Atas dasar peryataan yang telah dikemukakan sebelumnya maka hipotesis yang dimunculkan adalah : Kinerja keuangan mempengaruhi nilai perusahaan.

\section{METODE PENELITIAN}

Penelitian ini adalah penelitian survey sebab dilakukan pada suatu populasi, tetapi data yang dipelajari adalah data sampel. Bila menurut tingkat eksplanasinya adalah penelitian asosiatif kausal, karena digunakan untuk mengetahui hubungan antara dua variabel atau lebih yang mengandung sebab akibat. Dan bila dilihat dari jenis datanya adalah metode penelitian analisis data kuantitatif. Populasi dalam penelitian ini adalah perusahaan-perusahaan yang terdaftar dalam LQ - 45 . Teknik sampling yang digunakan adalah sampel jenuh, sehingga seluruh populasi adalah sampel. Dengan demikian terdapat 135 perusahaan yang dijadikan populasi sekaligus sampel.

Bila dilihat dari penggunaan sampel yang berarti kategori penelitian survey, maka menurut Sugiyono (2003), teknik statistik yang harus dipergunakan adalah 
teknik statistik Inferensial. Sebab statistik inferensial dipergunakan untuk menganalisis data sampel dan hasilnya diberlakukan untuk populasi.

Statistik inferensial sendiri dibagi menjadi dua yaitu statistik parametris dan non parametris. Untuk penelitian ini dipergunakan statistik parametris sebab digunakan untuk menguji parameter ukuran populasi melalui data sampel dan jenis data adalah data rasio. Uji asumsi klasik dilakukan dengan menggunakan SPSS 14 for Windows, antara lain uji Kolmogorov-Smirnov untuk menguji apakah data berdistribusi normal. Uji heteroskedastisitas untuk mengetahui bahwa tidak ada variabel yang berpengaruh signifikan terhadap nilai residual sehingga model regresi terbebas dari masalah heteroskedastisitas. Nilai DurbinWatson untuk mengetahui data terletak pada daerah penerimaan sehingga tidak terjadi autokorelasi. Uji multikolinearitas untuk mengetahui bahwa tidak terjadi multikolinearitas. Untuk menguji Hipotesis yang pertama, maka dipergunakan Teknik Analisis data yaitu Regresi.

\section{HASIL DAN PEMBAHASAN}

Uji $\mathrm{t}$ digunakan untuk mengetahui apakah variabel bebas mempunyai pengaruh yang signifikan terhadap variabel terikat secara parsial. Jika hasilnya signifikan maka Ha diterima, sedangkan jika hasilnya tidak signifikan maka $\mathrm{Ha}$ ditolak.

Berikut ini adalah Hasil pengujian uji $\mathrm{t}$ antara kinerja keuangan (X) terhadap nilai perusahaan (Y).

Tabel 1. Hubungan Regresi Antara Variabel Bebas Dengan Variabel Terikat Secara Parsial

\begin{tabular}{|c|c|c|c|c|c|c|c|c|c|c|}
\hline \multirow[t]{2}{*}{ Model } & & \multicolumn{2}{|c|}{$\begin{array}{l}\text { Unstandardized } \\
\text { Coefficients }\end{array}$} & \multirow[t]{2}{*}{$\mathrm{T}$} & \multirow[t]{2}{*}{ Sig. } & \multicolumn{3}{|c|}{ Correlations } & \multicolumn{2}{|c|}{$\begin{array}{l}\text { Collinearity } \\
\text { Statistics }\end{array}$} \\
\hline & & $\mathrm{B}$ & Std. Error & & & $\begin{array}{l}\text { Zero- } \\
\text { order }\end{array}$ & $\begin{array}{l}\text { Parti } \\
\text { al }\end{array}$ & Part & Tolerance & VIF \\
\hline 1 & (Constant) & -.146 & .711 & -.205 & .038 & & & & & \\
\hline & R.OE & .087 & .030 & 2.854 & .005 & .238 & .245 & .224 & .978 & 1.022 \\
\hline
\end{tabular}

Sumber: Data Diolah (2015)

Berdasarkan tabel diatas, maka hasil perhitungan korelasi parsial diperoleh angka signifikansi sebesar 0,005 kurang dari nilai probabilitas 0,05, maka hipotesis yang pertama hasilnya $\mathbf{H}_{1}$ diterima. Artinya, ada pengaruh (hubungan linier) antara kinerja keuangan (X) dengan nilai perusahaan (Y). Besarnya pengaruh kinerja keuangan $(\mathrm{X})$ terhadap nilai perusahaan $(\mathrm{Y})$ sebesar $\mathrm{r}^{2}=$ $(0,245)^{2}$ yaitu 0,06 atau sebesar $6 \%$ atau dianggap signifikan.

Berdasarkan pada hasil pengolahan data melalui analisis regresi secara parsial, maka kinerja keuangan (X) memiliki pengaruh terhadap nilai perusahaan sebesar 6\%. Dengan demikian Informasi dari perusahaan yang masih menjadi bahan pertimbangan dalam mengeksekusi pilihan berinvestasi adalah informasi tentang kinerja keuangan pada perusahaan-perusahaan yang masuk dalam daftar LQ-45 untuk periode 2006 sampai dengan 2008. Hal ini sejalan dengan penelitian yang dilakukan oleh Christiawan dan Tarigan (2007) dalam penelitiannya 
menyatakan Kinerja Keuangan berpengaruh positif terhadap nilai perusahaan. Penelitian ini mengambil sample sebesar 137 perusahaan yang terdapat di Bursa Efek Jakarta selama tiga periode yaitu dari tahun 2003 sampai dengan 2005.

Kinerja keuangan pada penelitian ini diukur dengan menggunakan ROE, nilai perusahaan dihitung dengan Tobins'Q. Pada tahun 2006 perusahaan yang prosentase ROEnya dibawah satu (1) sebanyak 7\%, sedangkan 93\% memiliki angka ROE lebih dari satu (1). Pada tahun 2007 perusahaan yang prosentase ROEnya dibawah satu (1) sebanyak 2\%, sedangkan $98 \%$ memiliki angka ROE lebih dari satu (1). Pada tahun 2008 perusahaan yang prosentase ROEnya dibawah satu (1) sebanyak 8\%, sedangkan 92\% memiliki angka ROE lebih dari satu (1).

Secara keseluruhan bila diamati, jumlah perusahaan yang mengalami kenaikkan nilai kinerja keuangan yang berasal dari ROE mulai tahun 2006 sampai dengan 2008 mengalami fluktuasi. Pada tahun 2006 jumlah perusahaan yang nilai kinerja keuangannya diatas rata-rata sebesar 40\%, sedangkan pada tahun 2007 menjadi $42 \%$ dan pada tahun 2008 menjadi 38\%. Sehingga menyebabkan nilai kinerja keuangan memiliki pengaruh sebesar $6 \%$ terhadap nilai perusahaan. Hal ini berarti para investor masih mempertimbangkan nilai ROE dalam mengambil keputusan untuk berinvestasi. Seperti diketahui pada umumnya, bahwa kinerja keuangan yang tercermin dalam laporan keuangan adalah merupakan salah satu sumber informasi yang dikeluarkan oleh perusahaan. Informasi akuntansi sangat bermanfaat untuk menilai pertanggungjawaban kinerja manajer. Agar bermanfaat dalam proses pengambilan keputusan maka informasi tersebut harus relevan dan reliabel. Dalam mengambil keputusan manajemen maka diperlukan informasiinformasi tentang keadaan perusahaan. Informasi yang dimaksud adalah kinerja keuangan perusahaan. Sedangkan kinerja keuangan perusahaan mencerminkan kemampuan perusahaan dalam mengelola operasional perusahaan. Kinerja keuangan suatu perusahaan sangat bermanfaat bagi berbagai pihak seperti investor, kreditur, analis, konsultan keuangan, pialang pemerintah dan pihak manajemen sendiri. Kinerja keuangan mengukur kinerja perusahaan dalam memperoleh laba dan nilai pasar.

Informasi yang relevan adalah informasi yang memiliki potensi untuk mempengaruhi keputusan yang diambil, sedangkan informasi yang reliabel adalah informasi yang tidak menyesatkan (dapat diandalkan). Sayangnya, informasi yang relevan sering kali tidak reliabel, dan sebaliknya informasi yang reliabel sering kali tidak relevan. Sampai saat ini akuntansi lebih mementingkan reliabilitas dari relevansi, sehingga informasi yang akhirnya tersaji sering kali kurang relevan. Secara umum perilaku seseorang terhadap resiko ada 3 jenis yaitu : 1.) Risk averse, adalah perilaku seseorang dimana diperlukan penmgkatan return untuk peningkatan risiko; 2.) Risk indifferent, adalah perilaku seseorang dimana tidak diperlukan peningkatan return untuk peningkatan risiko; 3.) Risk seeking, adalah perilaku seseorang dimana sekalipun return menurun, tidak takut menghadapi risiko

Agar dapat berguna, laporan ini harus membantu memprediksikan hasilhasil pengembalian investasi di masa akan datang. Dari informasi akuntansi berupa laporan keuangan dapat dibuat suatu analisis rasio keuangan. Analisis rasio keuangan merupakan instrumen analisis prestasi perusahaan yang menjelaskan berbagai hubungan dan indikator kinerja keuangan yang ditujukan untuk menunjukkan perubahan dalam kondisi keuangan atau prestasi operasi di masa 
lalu dan dipergunakan untuk melakukan prediksi dimasa yang akan datang. Makna dan kegunaan rasio keuangan dalam praktik bisnis pada kenyataannya bersifat subyektif, bergantung pada untuk apa suatu analisis dilakukan dalam konteks apa analisis tersebut diaplikasikan.

Para investor harus diperhatikan oleh perusahaan dengan cara memaksimalkan nilai perusahaan tersebut, nilai perusahaan merupakan ukuran keberhasilan atas pelaksanaan fungsi-fungsi keuangan. Penilaian prestasi suatu perusahaan dapat dilihat dari kemampuan perusahaan itu untuk menghasilkan laba. Laba perusahaan selain merupakan indikator kemampuan perusahaan memenuhi kewajiban bagi para penyandang dananya juga merupakan elemen dalam penciptaan nilai perusahaan yang menunjukkan prospek perusahaan di masa yang akan datang. Tingkat profitabilitas perusahaan dapat diukur dari beberapa aspek, yaitu berdasarkan pada rasio profitabilitas. Rasio profitabilitas menurut Brigham dan Houston (2006) terdiri dari rasio yaitu: gross profit margin (GPM), basic earning power (BEP), return on asset (ROA) atau sering disebut return on investment (ROI), dan return on equity ( $\mathrm{ROE})$.

Untuk mengukur kinerja perusahaan dari sisi pandang investor menurut Brigham dan Houston (2006) adalah dengan menggunakan pendekatan return on equity (ROE). Alasan penggunaan rasio tersebut menurut Brigham dan Houston (2006) adalah para pemegang saham melakukan investasi untuk mendapatkan pengembalian atas uang mereka dan rasio ini menunjukkan seberapa baik mereka telah melakukan hal tersebut dilihat dari kacamata akuntansi. Hal ini diperkuat dengan pernyataan Halsey dan Wild (2005) yang menyatakan pengembalian atas investasi merupakan ukuran kinerja yang diakui secara luas. Ukuran ini memungkinkan untuk menilai pengembalian perusahaan terhadap resiko investasi modal. Bodie, dkk (2006) juga menguatkan alasan penggunaan rasio return on equity dengan menyatakan imbal hasil atas investasi adalah ukuran yang paling populer, perusahaan dengan tingkat imbal hasil yang tinggi seharusnya lebih mampu menghasilkan uang dipasar modal karena mereka menawarkan imbal hasil yang lebih baik kepada calon investornya.

Salah satu tahapan dalam proses akuntansi yang penting untuk keperluan pengambilan keputusan manajemen adalah tahap interprestasi laporan akuntansi, yang didalamnya mencakup rasio keuangan. Rasio keuangan yang merupakan bentuk informasi akuntansi yang penting bagi perusahaan selama suatu periode tertentu. Berdasarkan rasio tersebut, dapat dilihat kinerja keuangan, maupun kinerja ekonomis di masa depan. Karena penilaian kinerja pada dasarnya merupakan penilaian perilaku manusia dalam melaksanakan peran yang dimainkannya dalam mencapai tujuan organisasi atau perusahaan.

Berdasar laporan keuangan diketahui kinerja keuangan perusahaan dengan cara melakukan analisis laporan keuangan melalui perhitungan rasio-rasio keuangan. Kinerja keuangan suatu perusahaan sangat bermanfaat bagi berbagai pihak seperti investor, kreditur, analis, konsultan keuangan, pialang pemerintah dan pihak manajemen sendiri. Kinerja keuangan mengukur kinerja perusahaan dalam memperoleh laba dan nilai pasar.

Untuk mengukur kinerja perusahaan dari sisi pandang investor menurut Brigham dan Houston (2006) adalah dengan menggunakan pendekatan return on equity (ROE). Alasan penggunaan rasio tersebut menurut Brigham dan Houston (2006) adalah para pemegang saham melakukan investasi untuk mendapatkan 
pengembalian atas uang mereka dan rasio ini menunjukkan seberapa baik mereka telah melakukan hal tersebut dilihat dari kacamata akuntansi. Hal ini diperkuat dengan pernyataan Halsey dan Wild (2005) yang menyatakan pengembalian atas investasi merupakan ukuran kinerja yang diakui secara luas. Ukuran ini memungkinkan untuk menilai pengembalian perusahaan terhadap resiko investasi modal. Bodie, dkk (2006) juga menguatkan alasan penggunaan rasio return on equity dan return on assets dengan menyatakan imbal hasil atas investasi adalah ukuran yang paling populer, perusahaan dengan tingkat imbal hasil yang tinggi seharusnya lebih mampu menghasilkan uang dipasar modal karena mereka menawarkan imbal hasil yang lebih baik kepada calon investornya.

Rata-Rata investor mempunyai kecenderungan untuk membeli atau meningkatkan saham mereka di dalam investasi ketika kondisi baik dalam waktu yang pendek atau singkat. Pada waktu yang sama, investor juga cenderung untuk menjual atau mengurangi saham mereka di dalam investasi ketika kondisi kurang baik dalam waktu yang pendek atau singkat. Investor merupakan suatu konstituen pengguna yang utama pada teori-teori keputusan dan investasi untuk memahami jenis informasi laporan keuangan yang dibutuhkan saat berinvestasi.

Teori keputusan satu orang menurut Scott (2003) mengambil sudut pandang seseorang yang harus membuat keputusan dalam kondisi-kondisi ketidakpastian. Agar informasi akuntansi berguna bagi pihak-pihak yang membutuhkannya, maka laporan keuangan harus disusun secara objektif dan relevan. Dengan demikian kinerja keuangan yang tercermin dalam laporan keuangan masih dipergunakan sebagai bahan pertimbangan dalam mengambil keputusan untuk berinvestasi.

\section{SIMPULAN}

Terdapat pengaruh (hubungan linier) antara kinerja keuangan dengan nilai perusahaan. Hal ini berarti para investor masih mempertimbangkan nilai ROE dalam mengambil keputusan untuk berinvestasi. Untuk penelitian selanjutnya disarankan untuk menambahkan variabel GCG ataupun moderating/intervening untuk mengetahui pola rasionalitas investor.

\section{DAFTAR RUJUKAN}

Belkaoui, Ahmed Riahi. 2000. Teori Akuntansi. Jakarta : Salemba Empat.

Bodie Zvi, Kane Alex, dan Marcus J Alan. 2006. Investasi. Jakarta : Salemba Empat.

Brigham F Eugene dan Houston F Joel. 2006. Dasar-dasar Manajemen Keuangan. Jakarta : Salemba Empat.

Christiawan, Jogi Yulius dan Tarigan Josua. 2007. Kebijakan Hutang, Kinerja Keuangan Dan Nilai Perusahaan. Jurnal akuntansi dan Keuangan UK PETRA, Vol. 9, No. 1, Mei 2007. Hal : 1-8.

Copeland, E Thomas dan Weston J Fred. 1995. Manajemen Keuangan. Jakarta : Bina Rupa Aksara.

Halsey, F Robert, Subramanyam K.R dan Wild J John. 2005. Analisis Laporan Keuangan. Jakarta : Salemba Empat. 
Jumingan. 2006. Analisis Laporan Keuangan. Jakarta : Media Grafika.

Mankiw, N Gregory. 2003. Teori Makro Ekonomi. Jakarta : Erlangga.

Miller, Alan. 2008. Farm Business Management for the $21^{\text {st }}$ Century Key Financial Performance Measures for Farm General Managers. Indiana US : Department of Agricultural Economics-Purdue University press.

Mulyadi. 1986. Akuntansi Biaya Untuk Manajemen. Yogyakarta : BPFE.

Prastowo, Dwi dan Rifka Juliaty. 2005. Analisis Laporan Keuangan Konsep dan Aplikasi. Yogyakarta : Unit Penerbit \& Percetakan AMP YKPN.

Scott, R William. 2003. Financial Accounting Theory. Toronto : Prentice Hall.

Sugiyono. 2003. Metode Penelitian Bisnis. Bandung : Alfabeta. 